\title{
Evaluation of a tanned red cell technique for thyroid microsomal antibodies
}

\author{
T. BIRD AND J. STEPHENSON
}

From the Department of Haematology, Newcastle General Hospital, Newcastle upon Tyne

SYNOPSIS A haemagglutination test for thyroid microsomal (cytoplasmic) antibodies, using formolized tanned sheep red cells, is described and evaluated. The technique is essentially similar to the thyroglobulin tanned red cell test. It has been shown to be more sensitive and easier to use than the complement-fixation test. A combined screening test to detect both thyroglobulin and microsomal antibodies is described.

Autoimmune thyroid disease is characterized by the presence in the serum of one or more of a number of antibodies to different components of thyroid gland.

Antibodies to thyroglobulin have been studied for many years by gel diffusion and latex fixation tests but the most widely adopted method is that using tanned red cells coated with thyroglobulin (Witebsky and Rose, 1956). The use of formolized tanned sheep red cells made the reagent more stable and easier to use (Fulthorpe, Roitt, Doniach, and Couchman, 1961), and since then the thyroidtanned red cell (TRC) test has been commonly performed with standardized cells obtained commercially from Burroughs Wellcome.

Antibodies to thyroid microsomal (cytoplasmic) antigens were demonstrated later by Trotter, Belyavin, and Waddams (1957) and by Roitt and Doniach (1958) using the complement-fixation test. Antigen is obtained from thyroid acinar cells by differential centrifugation of homogenates of thyrotoxic thyroid gland and the test is widely used (commonly with antigen obtained commercially from Burroughs Wellcome). It is now generally accepted, however, that the indirect immunofluorescence technique, using fresh thyrotoxic thyroid as substrate, is the more sensitive (Doniach, 1967).

Antibody to a second antigen in colloid $\left(\mathrm{CA}_{2}\right)$ has also been demonstrated, using an immunofluorescent technique with fixed thyroid gland (Balfour, Doniach, Roitt, and Couchman, 1961). This antigen may be a thyroid protease and the test is said to be of greatest value in rare cases of

Received for publication 12 June 1973.
Hashimoto's disease where all other antibody tests are negative.

Tests for the first two antibodies have been those most widely used, and there is now an extensive literature on their value in the assessment of thyroid function, both in established disease and grades of hypothyroidism (Evered, Ormston, Smith, Hall, and Bird, 1973), and in population surveys. The thyroglobulin TRC test has been made easier, more convenient, and probably more reproducible and accurate by the use of Takatsy micro-titre apparatus and trays instead of the original tubes or MRC trays and pipettes. Together with standardized formolized tanned sheep red cells, it has also produced lower titres of antibody, and the sometimes astronomical levels previously recorded are rarely seen now. The increased availability of reliable commercial antisera, and the development of cheaper and more convenient microscope and illumination equipment have allowed the Coons indirect immunofluorescent technique, using fluorescein-isothiocyanate conjugated antihuman globulin to become more widely used. The complement-fixation test is still used either in its own right or as an indication of the strength of the microsomal antibody (Doniach, 1967).

Problems of preparation and standardization occur in complement-fixation tests due to variations in antigen, haemolytic serum, sheep red cells, complement, and buffer, and thyroid antigen, obtained commercially, is relatively expensive, especially if used as a screening test for large numbers of sera. A test for microsomal antibodies, using essentially the same technique as the TRC test for thyroglobulin, would be of great advantage in a 
laboratory already doing thyroid antibody tests. The ability to combine two tests would immediately produce a saving in time, training, and cost, if the new test could be shown to be at least as good as the complement-fixation test.

Such a test (Microsome Test, Fujizoki) ${ }^{1}$ has recently become available. Formolized tanned sheep red cells are coated with a microsomal antigen prepared from thyroid acinar cells by super speed centrifugation of thyrotoxic thyroid gland. It was decided to assess this new reagent using sera which were known to be positive for microsomal antibodies by the immunofluorescent technique. These were all confirmed again at the time of assessment. Complement-fixation and thyroglobulin TRC tests were also performed at the same time as the Microsome test. Results of other tests of thyroid function, including serum protein-bound iodine, tri-iodothyronine, thyroxine, and thyroid-stimulating hormone (TSH) levels were available in almost all these patients.

\section{Microsome Test}

The reagents are supplied in kit form.

\section{ABSORBING FLUID}

This consists of $0.15 \mathrm{M}$ phosphate buffer saline (pH 7.2) to which has been added normal rabbit serum, cow and sheep cell stroma, and sodium azide. This is used to dilute serum and preabsorb non-specific antibodies, such as Forsmann, and to prepare working dilutions of the sensitized and unsensitized sheep cell suspensions.

\section{SENSITIZED SHEEP CELLS}

Lyophilized sensitized sheep cells containing, when rehydrated with $2.5 \mathrm{ml}$ of distilled water, a $2.5 \%$ suspension of formolized tanned cells coated with thyroid microsomal antigen. This is diluted 1 part to 2 parts of absorbing fluid to give a working suspension. This appears to keep well at $2-5^{\circ} \mathrm{C}$ but it is best to prepare only sufficient for each series of tests.

3 UNSENSITIZED TANNED SHEEP RED CELLS Lyophilized unsensitized formolized tanned sheep red cells, reconstituted with $1 \mathrm{ml}$ of distilled water to give a $2 \cdot 5 \%$ suspension, and used as above.

\section{POSITIVE CONTROL SERUM}

Lyophilized positive control serum which is a 1:100 dilution when reconstituted.

Assorted pipettes are.required.

'Obtainable in the UK from Diamed Diagnostics, 38 Queensland St, Liverpool L7 3JG.

\section{TECHNIQUE}

The instructions given in the kit are rather verbose and have suffered, in places, during translation from the original Japanese. A micro-haemagglutination technique is described and Takatsy-type microtitre apparatus is recommended but other trays and pipettes can be used. A macro-method is also described, but this only appears to be more costly, and we have confined our studies to the micromethod.

After inactivation of test sera at $56^{\circ} \mathrm{C}$ for 30 minutes $0.01 \mathrm{ml}$ is used to prepare an initial $1: 25$ dilution with absorbing dilutent. From this they recommend quadrupling dilutions from 1:100 to 1:1 638400 , through a series of nine cups, each finally containing $0.075 \mathrm{ml}$. These are left at room temperature for 30 minutes to allow absorption of non-specific antibodies, then $0.025 \mathrm{ml}$ of the $1: 3$ dilution of sensitized sheep cells is added to each cup. The tenth cup contains a 1:100 dilution of the test serum to which is added $0.025 \mathrm{ml}$ of unsensitized sheep cells as a control.

Reagent controls are also used by adding sensitized and unsensitized red cells to the absorbing diluent, and a known positive serum at a dilution of 1:100 is also tested. The trays are tapped to produce mixing, covered, and incubated overnight before reading. The results are read in the same manner as in the thyroid TRC test, viewing the tray from above against a white background with light coming across the bottom surface. A $2+$ positive result is defined as a smooth carpet of cells over the bottom of the cup, and a $1+$ result as a smooth carpet of cells surrounding a smaller red circle. A negative test is seen as a compact button of cells. A positive serum is defined as one showing a reaction of $1+$ or more at a dilution of $1: 100$, with the endpoint as the highest dilution showing a $1+$ reaction or more. We have found that positive results can be differentiated readily from negative results but that the endpoint is not always as easy to identify as in the thyroglobulin TRC test, especially in those sera with higher titres. This may well be because their $1+$ reaction is rather similar to the $( \pm)$ reaction, regarded as negative by Fulthorpe et al (1961).

We carried out the test according to the instructions but then decided to modify the dilution technique. Many workers with the TRC test use serum dilutions of $1: 5,1: 10$, and then 10-fold dilutions up to $1: 2500000$ or more, according to the method of Fulthorpe et al (1961). We have preferred to use doubling dilutions in the microsome method after experience had shown that the titres rarely reached the high levels found in the thyroid TRC test. Takatsy trays, with conical cups and micro-titre 
apparatus were used, but the MRC type plates and pipettes can also be used.

\section{Results}

The Microsome test was first compared with the complement-fixation test in a group of 150 cases all shown to have microsomal antibodies by the immunofluorescence technique. Many of these were cases with thyroid disease, with abundant supporting clinical and biochemical evidence, while others were patients with pernicious anaemia and general hospital patients suspected of having thyroid disease. Complement-fixation tests were performed using Burroughs Wellcome reagents. We have regarded a titre of $1: 16$ as positive, because of the number of false positives we have enountered during the last three years if $1: 4$ or $1: 8$ are accepted. The indirect Coons technique was performed using $5 \mu \mathrm{m}$ cryostat sections of fresh human thyrotoxic thyroid. The block also included mouse stomach, kidney and liver, rat liver, and human kidney, to assess other antibodies, both organ specific and non-specific, and to exclude non-specific microsomal antibodies. Positive thyroid fluorescence tests were graded as positive and strong positive. It is realized that many workers will not accept grading of fluorescence because of difficulties in standardization of the test conditions. We have obtained good reproducibility and these tests were carried out over a very short period of time with the same batch of reagents and the same microscope illumination (Zeiss Universal with an HBO 200 ultraviolet lamp and Ploem incident light illumination). We used grading in the hope that it might show the comparative values of the Microsome and complement-fixation tests.
The results are shown in table I which shows that the Microsome test was positive in $88 \%$ of the cases, while the complement-fixation test was positive in only $73 \%$. Both tests were positive in more than $90 \%$ of the cases showing strongly positive fluorescence but the Microsome test showed better correlation in the sera showing lesser grades of fluorescence.

The Microsome test was then used in the investigation of the next thousand patients referred to the laboratory for antibody tests of all types. They were from many different sources, including two 'normal' population surveys. The results are shown in table II.

The sera of 162 patients were positive for thyroid microsomal antibodies by the immunofluorescent technique, and again the Microsome test $(78 \%)$ showed a better correlation than the complementfixation test $(50 \%)$. The poorer correlation of both tests may be due to the fact that this group contained a large number of patients with no evidence, or clinical suspicion, of thyroid disease.

After excluding all sera which contained thyroid antibodies, the remainder included 54 with gastric parietal cell antibody, seven with mitochondrial antibody, 47 with nuclear antibody, seven with smooth-muscle antibody, four with reticulin antibody and eight with a positive Rose-Waaler reaction. None of these were positive with the Microsome and complement-fixation tests, except one with mitochondrial antibody. There was other evidence suggesting that this patient also had thyroid microsomal antibody, but this can be difficult to assess in the presence of a strong mitochondrial antibody (Walker, Bates, Doniach, Ball, and Sherlock, 1972).

In this group there were also 32 cases with antibodies to thyroglobulin by the TRC test, varying in titre from $1: 20$ to $1: 10000$, with no antibodies

\begin{tabular}{|c|c|c|c|c|c|c|c|c|c|c|c|c|c|c|}
\hline \multirow{2}{*}{$\begin{array}{l}\text { Thyroid } \\
\text { Cytoplasmic } \\
\text { Fluorescence }\end{array}$} & \multirow[t]{2}{*}{ No. } & \multicolumn{6}{|c|}{ CFT Titre } & \multicolumn{7}{|c|}{ Microsome Titre } \\
\hline & & $\begin{array}{l}\text { Nega- } \\
\text { tive }\end{array}$ & $1 / 16$ & $1 / 32$ & $1 / 64$ & $>1 / 64$ & $\begin{array}{l}\text { Total } \\
\text { Positive }\end{array}$ & $\begin{array}{l}\text { Nega- } \\
\text { tive }\end{array}$ & $1 / 100$ & $1 / 200$ & $1 / 400$ & $>1 / 400$ & $\begin{array}{l}\text { Total } \\
\text { Positive }\end{array}$ & $\%$ \\
\hline $\begin{array}{l}\text { Positive } \\
\text { Strong positive } \\
\text { Total }\end{array}$ & $\begin{array}{r}92 \\
58 \\
150\end{array}$ & $\begin{array}{r}35 \\
6 \\
41\end{array}$ & $\begin{array}{r}9 \\
1 \\
10\end{array}$ & $\begin{array}{r}22 \\
7 \\
29\end{array}$ & $\begin{array}{l}21 \\
19 \\
40\end{array}$ & $\begin{array}{r}5 \\
25 \\
30\end{array}$ & $\begin{array}{r}57(62 \%) \\
52(90 \%) \\
109(73 \%)\end{array}$ & $\begin{array}{r}16 \\
3 \\
19\end{array}$ & $\begin{array}{l}30 \\
12 \\
42\end{array}$ & $\begin{array}{l}34 \\
21 \\
45\end{array}$ & $\begin{array}{r}9 \\
13 \\
22\end{array}$ & $\begin{array}{r}3 \\
9 \\
12\end{array}$ & $\begin{array}{r}76 \\
55 \\
131\end{array}$ & $\begin{array}{l}82 \\
95 \\
88\end{array}$ \\
\hline
\end{tabular}

Table I Results in 150 patients with proven or probable thyroid disease

\begin{tabular}{|c|c|c|c|c|c|c|c|c|c|c|c|c|c|c|}
\hline \multirow{2}{*}{$\begin{array}{l}\text { Thyroid } \\
\text { Cytoplasmic } \\
\text { Fluorescence }\end{array}$} & \multirow[t]{2}{*}{ No. } & \multicolumn{6}{|c|}{ CFT Titre } & \multicolumn{7}{|c|}{ Microsome Titre } \\
\hline & & $\begin{array}{l}\text { Nega- } \\
\text { tive }\end{array}$ & $1 / 16$ & $1 / 32$ & $1 / 64$ & $>1 / 64$ & $\begin{array}{l}\text { Total } \\
\text { Positive }\end{array}$ & $\begin{array}{l}\text { Nega- } \\
\text { tive }\end{array}$ & $1 / 100$ & $1 / 200$ & $1 / 400$ & $>1 / 400$ & $\begin{array}{l}\text { Total } \\
\text { Positive }\end{array}$ & $\%$ \\
\hline $\begin{array}{l}\text { Positive } \\
\text { Strong positive } \\
\text { Total }\end{array}$ & $\begin{array}{r}104 \\
58 \\
162\end{array}$ & $\begin{array}{l}69 \\
13 \\
82\end{array}$ & $\begin{array}{r}10 \\
6 \\
16\end{array}$ & $\begin{array}{l}18 \\
12 \\
30\end{array}$ & $\begin{array}{r}4 \\
14 \\
18\end{array}$ & $\begin{array}{r}4 \\
13 \\
17\end{array}$ & $\begin{array}{l}36(35 \%) \\
45(76 \%) \\
81(50 \%)\end{array}$ & $\begin{array}{r}31 \\
4 \\
35\end{array}$ & $\begin{array}{r}25 \\
6 \\
31\end{array}$ & $\begin{array}{l}21 \\
16 \\
37\end{array}$ & $\begin{array}{l}22 \\
12 \\
34\end{array}$ & $\begin{array}{r}5 \\
20 \\
25\end{array}$ & $\begin{array}{r}73 \\
54 \\
127\end{array}$ & $\begin{array}{l}70 \\
93 \\
78\end{array}$ \\
\hline
\end{tabular}

Table II Results in 1000 consecutive patients referred to the laboratory for tissue-antibody tests 
demonstrable by immunofluorescence. The Microsome test was negative with all these sera.

\section{Absorption Tests}

Sera which were positive by both the thyroglobulin TRC test and the Microsome test were examined. Absorption with thyroglobulin removed the antibody to thyroglobulin but did not affect the titre of the Microsome test. Absorption with microsomal antigen, using the complement-fixing antigen supplied by Burroughs Wellcome, similarly removed the antibody demonstrated by the Microsome test. It also produced a reduction in the titre of thyroglobulin antibody which might be due to the presence of thyroglobulin in the antigen.

\section{Screening Test for Antibodies}

Following these results we have substituted a modification for screening purposes, using Takatsy trays and micro-titre apparatus to determine the presence of antibodies to both thyroglobulin and microsomal antigen.

\section{EQUIPMENT}

Takatsy micro-titre plates, containing $12 \times 6$ conical cups; Takatsy 'loops' and pipettes, each delivering $0.025 \mathrm{ml} ; 50 \times 9.5 \mathrm{~mm}$ tubes (blood grouping tubes); and suitable racks for tubes, preferably matching the arrangement of Takatsy trays.

\section{REAGENTS}

Buffered nørmal saline; microsome absorbing diluent; microsome tanned red cells; thyroglobulin tanned red cells (Burroughs Wellcome); and positive and negative sera for both antibodies.

\section{METHOD}

The Takatsy trays are divided 'vertically' and numbered with a felt-tipped pen so that each serum is apportioned to three cups. One $50 \times 9.5 \mathrm{~mm}$ tube for each specimen is placed in a rack, matching the serum specimen, and into each is delivered $0.225 \mathrm{ml}$ of saline. Then $0.025 \mathrm{ml}$ of saline is placed in cups 1 and 2 and $0.025 \mathrm{ml}$ of absorbing diluent into cup 3 . A loop, carefully loaded with $0.025 \mathrm{ml}$ of test serum, is placed in its appropriate tube and thoroughly mixed, to give a 1:10 dilution. After mixing the loaded loop is transferred to cup 1 and mixed, transferred to cup 2 and mixed, and then finally to cup 3, the last loopful being discarded. The loop is then rinsed, blotted dry, and flamed to clean before subsequent use. The resultant dilutions are 1:20 and $1: 40$ in saline and 1:80 in absorbing diluent.
With the micro-titre apparatus up to six specimens can be diluted at a time, and 24 specimens can be accommodated in each tray. The trays are then covered and left at room temperature for $\mathbf{3 0}$ minutes to allow absorption of non-specific antibodies in the Microsome test. Now $0.025 \mathrm{ml}$ of thyroglobulin tanned red cells is added to the first two cups, and $0.025 \mathrm{ml}$ of suitably diluted Microsome tanned red cells to the third cup. The trays are tapped gently to mix, covered, and left for two hours at room temperature, then examined for agglutination. Any sera showing positive or doubtful results in either or both tests are noted, removed from the racks, and the full quantitative test is then performed. Absorption with sheep red cells of the sera for thyroglobulin antibodies can then be performed, but in practice we have found that there is rarely, if ever, any evidence of non-specific antibodies at the dilutions used of $1: 20$ and $1: 40$. If saline is used for dilution in the Microsome test, the endpoint is not so readily determined as with absorbing diluent. Known positive and negative sera are tested with every batch.

Tests have shown that inactivation of serum at $56^{\circ} \mathrm{C}$ is not required when the Microsome test is used at dilutions of $1: 80$ or more and as a titre of $1: 100$ is needed for acceptance as positive, we have left out this procedure. By restricting the dilutions to those regarded as significant for both antibodies, no time or reagent is wasted on negative sera.

This technique has been shown to be of great value in two large population surveys at present in progress and also in the screening of patients referred for investigation of thyroid and allied disorders.

\section{Discussion}

The immunofluorescent technique is generally accepted as the best and most sensitive test for thyroid microsomal antibodies. Our results show that the Microsome test correlates better with it than does the complement-fixation test. During the last three years the complement-fixation test has, in our hands, been positive in only approximately $55 \%$ of fluorescence-positive cases, results which are not greatly dissimilar from those of other workers with wider experience in this field (Belyavin, 1964). This difference may not be entirely due to defects in the test. Microsomal antibody is cytotoxic to thyroid acinar cells in culture but the results correlate better with immunofluorescent tests than the complement-fixation test (Doniach, 1967). Rose, Skelton, Kite, and Witebsky (1966) state that in experimental thyroiditis in monkeys thyroid-specific complement fixation can be demonstrated in the 
absence of cytotoxic effects and suggest that there may be two different antibodies reacting with microsomal fractions.

The Microsome test, even if it had shown no greater sensitivity, still has many advantages over the complement-fixation test. It is much easier to perform, has fewer reagents to control, and can be combined with the thyroglobulin TRC test with very little extra effort, producing a great saving in time. A reasonably experienced technician can comfortably handle at least 100 Microsome and thyroglobulin TRC tests a day, including those requiring full quantitative titration, and have time to carry out other duties during the periods of incubation. Because only minimal preparation is required the tests can be conveniently used for small or large batches of sera. Using the screening results we have found that approximately $80 \%$ of thyroid antibodies (detected by immunofluorescent techniques) would have been shown by the combined TRC and Microsome tests, but only $60 \%$ by TRC and complement-fixation tests.

We have not found any false positive tests in the absence of other positive tests for thyroid antibodies and zoning of antibodies has not been detected.

The suppliers suggest that each Microsome kit, costing $£ 6$, will provide 70 micro tests (or 10 macro tests). Despite the high titres quoted in their literature, we have found that the level rarely rises above $1: 800$ and the highest seen to date is $1: 12800$. In practice, up to 100 quantitative tests can be obtained from a kit, and, if screening methods are used, several hundred sera can be tested, the number depending on how many require full titration. We have estimated that the reagent costs approximately one-quarter to one-third of the cost of commercial reagents for complement-fixation tests.

It would thus seem that this technique has many advantages over the complement-fixation test for the detection of thyroid microsomal antibodies.

The work was aided by a grant to T.B. from the Scientific and Research Committee of the Newcastle University Hospital Group.

We would like to thank Mr C. Gregory for technical help, and Miss Sonia Humphries for secretarial assistance.

\section{References}

Balfour, B. M., Doniach, D., Roitt, I. M., and Couchman, K. G. (1961). Fluorescent antibody studies in human thyroiditis: auto-antibodies to an antigen of the thyroid colloid distinct from thyroglobulin. Brit. J. exp. Path., 42, 307-316.

Belyavin, G. (1964). Immunological aspects of thyroid disease. The antibody response, In The Thyroid Gland, edited by $\mathbf{R}$. Pitt Rivers and W. R. Trotter, pp. 298-317. Butterworths, London.

Doniach, D. (1967). Thyroid autoimmune disease: symposium on Thyroid Gland, 1966. J. clin. Path., 20, 385-390.

Evered, D., Ormston, B. J., Smith, P. A., Hall, R., and Bird, T. (1973). Grades of hypothyroidism. Brit. med. J., 1, 657-662.

Fulthorpe, A. J., Roitt, I. M., Doniach, D., and Couchman, K. (1961). A stable sheep cell preparation for detecting thyroglobulin auto-antibodies and its clinical applications. J. clin. Path., 14, 654-660.

Roitt, I. M., and Doniach, D. (1958). Human auto-immune thyroiditis: serological studies. Lancet, 2, 1027-1033.

Rose, N. R., Skelton, F. R. F., Kite, J. H., Jr., and Witebsky, E. (1966). Experimental thyroiditis in the Rhesus monkey III: course of the disease. Clin. exp. Immunol., 1, 171-188.

Trotter, W. R., Belyavin, G., and Waddams, A. (1957). Precipitating and complement-fixing antibodies in Hashimoto's disease. Proc. roy. Soc. Med., 50, 961-962.

Walker, J. G., Bates, D., Doniach, D., Ball, P. A. J., and Sherlock, S. (1972). Chronic liver disease and mitochondrial antibodies: a family study. Brit. med. J., 1, 146-148.

Witebsky, E., and Rose, N.R. (1956). Studies on organ specificity. IV. Production of rabbit thyroid antibodies in the rabbit. $J$. Immunol., 76, 408-427. 